\title{
Hermeneutics of Theological Anthropology
}

Hermeneutics is well known to theologians for its use in the Holy Bible. The set of principles guiding its interpretation is called biblical hermeneutics. However, nowadays there is also talk of theological hermeneutics, and even theology as a whole is understood as a specific kind of hermeneutics.

It is well known that in addition to the text of the Bible, theology has to deal with numerous other texts, the meaning of which it has to explain. These are the patristic, theological and especially doctrinal texts of the Church. In a similar way to the Bible, all these texts need to be interpreted in light of historical and cultural circumstances, in the context of theological tradition and faith. This is the undeniable task of theology, which, starting with biblical themes, is to show "what the Fathers of the Church of the East and the West have contributed to the faithful transmission and explanation of the individual truths of revelation, as well as to the further history of dogma, taking into account its relationship to the general history of the Church."

However, theological hermeneutics can be described in another sense, namely, as the inclusion of ourselves in the theological work i.e. the man of today who, in a concrete cultural and existential situation, examines God's revelation: he asks him questions and awaits the answers. One could say that theological hermeneutics understood in this way requires the consideration of another "text" or rather a whole series of different texts, namely those that speak of ourselves and our existential situation.

Theological hermeneutics understood in this way derives from contemporary philosophical hermeneutics, which is practiced by M. Heidegger and H.-G. Gadamer. ${ }^{2}$

OT, 16.

M. Heidegger, Sein und Zeit, Tiibingen 1963, H.-G. Gadamer, Wahrheit und Methode, Tübingen 1965 . 
Heidegger begins from the fact that a human being is born as Dasein, the existence, as a man in the world. He states that the historicity of man (des Daseins) does not constitute a limitation of his cognition and does not threaten the objectivity of this cognition. However, the very situation of a human being in the world, the very historicity of the human being, and thus all that concerns the subject of cognition, should be taken into account and carefully disclosed.

Moreover, the theological hermeneutics we are talking about is based to a certain extent on Bultmann's views ${ }^{3}$. He preached the need to demythologize the Bible in order to reach, through its mythological layer, the salvific event of the encounter of an ever-living man with the Word of God.

Catholic theology cannot ignore this hermeneutical problem, which is the inclusion of the subject itself and its conditions in cognition. On the contrary, work on such theological hermeneutics is considered a necessity which cannot be overestimated. ${ }^{4}$

The Word of God i.e. revelation has, we believe, permanent meaning. It is a living word, always up to date, always salvific. However, it does not identify with any theological statement, with any dogmatic term, and even the Bible is already its interpretation. We are therefore dealing with a whole series of historical interpretations of the Word of God which are a function not only of understanding the Bible and Tradition, but also of the understanding of oneself and one's own culture, which a human being had in different times. Theology is not only about determining the meaning of the biblical text, or any subsequent historical interpretation of it. We would then be dealing with biblical theology or with the history of theology. The theologian should seek to understand the Word of God itself, which implies a knowledge not only of the meaning of the Bible, later theological and doctrinal statements, but also of own cultural situation. "The understanding of faith and the interpretation of oneself are inseparable. The history of salvation can only be interpreted in a living interpretation of oneself as a historical being, situated in tradition and in a particular culture."

I do not think it is reasonable to doubt that theology always fulfils this role in some way. This is where the differences we point to come from, e.g. between theology in Antiquity, in the Middle Ages or Modernity, although, of course, each time and culture could be characterised by the characteristics

3 R. Bultma, Neues Testament unh Mythologie, Tübingen 1941; Theologie des Neuen Testaments, Tübingen 1961; Glauben und Verstehen, 4 vol., Tübingen 1933-1965; Kerygma und Mythos,. H. W. Bartsch, 4 vol., Hamburg 1948.

4 K. Lehmann, Heimeneutik, in: Sacramentum Mundi, vol. 2, 683.

5 C. Geffre, Un nouvelle âge de la theologie, Paris 1972, 60 f. 
of the theology practised at that time. Today, however, we are more aware of the hermeneutical nature of our inquiries and their facts, just as we are more aware of the complexity of the Bible as a historical and literary work and, above all, of the relationship between the biblical text and the divine revelation expressed in it; how more we are aware of what is termed Sitz im Leben of every dogmatic term.

We do not have of course ready-made worked-out theological hermeneutics. Individual theologians only try to define it or to delineate its individual elements. K. Rahner focuses primarily on subjective conditions, treating theology as transcendental anthropology. ${ }^{6} \mathrm{P}$. Ricoeur analyses the language of religion in its original layer, which is a symbolic language. This language says something about a human being living in a world of certain values and making constant choices. Through this symbolic religious language, Transcendence appeals to a human being ${ }^{7}$. Each epoch has its own ability to express faith (le croyable disponible). ${ }^{8}$ Pannenberg, Moltmann, Metz put greater emphasis on the historical and social context of understanding the message of the gospel, taking into account the forward-looking and eschatological attitude of human existence and history. ${ }^{9}$ E. Schillebeeckx is convinced that the fundamental hermeneutical question is not: what is the attitude of the past (Tradition, the Bible) to the present, but: what is the connection between theory and practice. Only "a practical reinterpretation judging the old practice in the light of the promise of the future. It corresponds to the real situation today, because it not only explains the past kindly, but also really transforms it," says Schoof ${ }^{10}$.

The hermeneutical problem expresses its proper methodological reflection in today's theology.

The actuality of hermeneutics in theology is connected with the pressure of various tasks and decisions that Christians and Christian churches are facing

$6 \quad$ K. Rahner, Teologia a antropologia, Znak 21 (1969), 1535-1551.

$7 \quad$ P. Ricoeur, Le contlit des interpretations. Essais d'hermeneutique, Paris 1969.

8 Ibid, Taches de la communaute ecclesiale dans le monde moderne, in: La theologie da renouveau (sous la dir. de L.K. Shook, G.M. Bertrand), Montreal-Paris 1968, vol. 2, 51-57.

$9 \quad$ W. Pannenberg, Grundiragen systematischer Theologie, Gottingen 1967, 91-158; J. Moltmann, Theologie der Hollnung, Munchen 1964; Id., Perspektiven der Theologie, Miinchen 1969; J. B. Metz, Zur Theologie der Welt, Mainz-Miinchen 1968; Id., Politische Theologie, in: Sacramentum Mundi, vol. 3., 1232-1240.

10 M. Schoof, Przełom w teologii katolickiej, Kraków 1972, 276-281. Cf. E. Schillebeeckx, O katolickie zastosowanie hermeneutyki, Znak 20 (1968), 978-1010; Z hermeneutycznych rozważań nad eschatologia, Conciłium 15 (1969), 3141; Intelligence de la ioi et interpretation de soi, in : heologie d'aujourd'hui et de domain, Paris 1967, 121-137. 
today. There is almost no area of human life in which there are no new facts and the consequent need to interpret them and make moral decisions. Changes in the world are followed by changes in the Church. There is probably no area of ecclesiastical life and there are no formulations of faith and so established ways of acting that do not require new analyses, formulations, and new solutions.

Such problems always appeared in Christian life, in theology, and in the Church. It has not always been easy to confront them with the message of revelation. Sometimes it led to serious conflicts. It took a long time to properly define the position of the Church and theology on the Copernican upheaval, on the theory of evolution, or workers' problem. At the same time, it is not easy to realise all the factors that led to one or another solution. Undoubtedly, the theoretical and theological considerations, research on sources and interpretation of faith to date played a role here, as did the developing beliefs of believers and the authority of ecclesiastical power, the development of secular sciences and culture in general, and so on. However, what role the various factors played, what considerations influenced the final direction of the development of faith and ecclesiastical teaching, is difficult to determine even today, in retrospect.

The situation today is characterised by several new features in this respect.

First of all, changes in human life take place incomparably increasingly more often and more rapidly than before. History teaches us that in the past Christians waited too long with the reform of ecclesiastical institutions, theology, with an open attitude to the changes taking place in the world. The present times, going faster, do not allow us to delay in solving growing problems and answering emerging questions.

Secondly, the development of humanities and anthropological sciences, as well as the organisation of science allow for a much more insightful and comprehensive interpretation of texts and cultural research than in the past. The development of theology and ecumenism makes it possible to take more fully into account certain elements of faith that have remained in the shadows so far, such as the eschatological dimension of human life, the communal character of the Church, etc.

Thirdly and finally, and this is related to the previous point, in every area of human life we encounter not only a passive interpretation of the past today but also forecasting and planning the future. We can talk about the desire to control and direct the development of culture, which until now was relatively spontaneous.

All this means the possibility, need and real development of theological hermeneutics. It is not only about interpreting old texts in the light of past, contemporary cultural texts, but also to interpret today's world, our culture, 
current events, in order to enable Christians and Christian Churches, in their confrontation with faith and revelation, to find solutions to problems facing them, that is, from the point of view of the Word of God, to understand the meaning of the Word of God in our existence. This understanding, even if outlined in general and incomplete terms, without the total certainty of a faith that matures gradually, will allow for a specific orientation of Christian action, for the involvement of Christians in the pressing problems of the world in which they live and which they are to build together with all their brothers and sisters; it will allow them to plan together the paths of development of the world with others in the hope of the Kingdom of God that they are expecting.

Theological hermeneutics necessarily brings in anthropological problems: being aware of the subjective conditions in theological cognition, examining the structure of the language of religion, reflecting on the phenomena of contemporary culture, confronting questions to which we seek answers in the texts we interpret, we turn around in the circle of anthropological issues.

Also taking into account the content of the texts that theology deals with when examining the subject of theology, we always face the problem of a human being in the end. Theology is about God, but about a God who salvages the human being. Revelation shows God, the Saviour and at the same time the salvaged man.

I would like to present here some formulations by E. Schillebeeckx concerning the basic approach to hermeneutical theological anthropology.

Schillebeeckx tries to make the most fundamental confrontation of the meaning of biblical texts and other testimonies of revelation with all that man knows about himself and his culture from elsewhere. It is probably difficult to get to know the author's thoughts comprehensively from a short fragment, but I think it is interesting to see even a partial performance of it. "The object of revelation is God's love for the world. The Bible teaches neither anthropology nor cosmology. It simply tells us that a man in the world is loved by God in God's way. What is man in the world must be explained by human experience, and therefore by history... Christianity does not teach us anything detailed in anthropology except that man has been introduced into the mystery of God's grace, or rather that man's mystery is, in its deepest layers, the mystery of God himself. In the course of history, man discovers the slow dimensions of his existence. Every new stage of this self-understanding must be illuminated by the only content of revelation, and in this new Dimension man must live a love for others, a love that draws its radical character from God's absolute and free love for man. Thus "Anthropology" is developed or discovered in its formal structures through the earthly experience of all people, whether Christians or 
non-Christians, and Revelation calls us to implant love at every stage of this anthropology"11.

I do not comment on the subject matter of the cited text. I refer to it because it is an excellent example of a hermeneutical approach to anthropological issues in theology. This is the role of theology: to interpret the biblical text expressing God's revelation and to confront its meaning with the understanding with which it has been read throughout history and its successive reinterpretations; with the understanding of man throughout history and with the present anthropology which is represented by today's human experience and by today's teachings about man and culture. This is why we asked not only theologians, but also Biblicists, philosophers and specialists in various "secular" sciences to participate in our session. We do not believe that theology should refer only to philosophy, although cooperation with this particular science has the longest tradition and it is difficult to think about theology without it. Today, after all, it is believed that theological work requires cooperation between all peoples, and theological anthropology, as I presented it, seems to be an excellent example of this.

From the whole of theological anthropology we can distinguish some specific issues which have always been of interest in theology and which have not lost their relevance even today. It is enough to mention such issues as the beginning of mankind and man, the structure of man, death, the final fate, the resurrection, in order not to enter the area of moral issues. As the subject of our session, we have chosen an issue that is somehow related to the context of human existence. These are matters with a very wide range of issues: man in the world of history and culture, man in relation to other people, and - as a result - the issue of man's relation to God.

In such a definition of the subject matter of our meeting, we were driven by the directions of thinking about man, characteristic, it seems, for contemporary culture and philosophy. The existence of man in his world, among others and in relation to God, is today, without the need to be proven, the privileged subject matter of the various sciences that deal with man and therefore also theological anthropology.

The topic of the first discussion is therefore a man in the world, i.e., in the world of history and culture. How are history and culture interpreted as texts testifying to man in today's cultural sciences? 
The second discussion will be about the community of people. What are inter-personal relationships? To what extent do they determine the structure of the human individual? How should we understand the human community, which is so often talked about today and which is so greatly sought after? At the same time, we can talk about community at different levels: living, historical, awareness. On the simply human community and on concrete communities.

Finally, the third discussion will be devoted to the issue of the relationship between man and God. It seems obvious today that there is a need to involve man in the face of other people, in the face of a self-created culture and the future. How to discover in all of this the right place for the relationship between man and God? How to overcome alleged competition from a so-called horizontal and vertical point of view?

We are aware of the fact that such a broad topic of discussion and participation of specialists from various disciplines conceals the danger of raising many different issues in a way parallel to each other, without being able to obtain a certain number of issues. However, in the course of this session we do not want to come up with a specific solution to the problems raised, or not even to outline the entirety of the issues indicated in the topics of the discussion. This is not possible. The aim of the discussion, as well as of the whole session, is a fragmentary orientation in border issues: theological anthropology and various sciences about man and culture, the aim of perceiving the field for theological hermeneutics procedures is to become more clearly aware of what theological anthropology treated as hermeneutics is. We hope to take this out of the session. 